\title{
Influence of row spacing and seeding rate on crop yields cultivated by "No-Till" technology in Kulunda steppe (Altai Region)
}

\author{
V. I. Belyaev', T. Meinel ${ }^{2}$, N. V. Rudev ${ }^{3}$, L.-Ch. Grunwald ${ }^{2}$, L. V. Sokolova ${ }^{4}$, \\ V. N. Kuznetsov ${ }^{1}$, A. V. Matsyura ${ }^{4^{*}}$ \\ ${ }^{1}$ Altai State Agricultural University, Barnaul, Russia \\ ${ }^{2}$ AMAZONEN-Werke $h$. Dreyer GmbH \& Co. KG, Hasbergen, Germany \\ ${ }^{3}$ LLC "Partner", Poluyamki, Michailovskiy District, Altai Region, Russia \\ ${ }^{4}$ Altai State University, Barnaul, Russia \\ "E-mail: amatsyura@gmail.com
}

Received Date: 23.10.2019 Accepted Date: 30.10.2019

\begin{abstract}
The long-term field experience has been carried out in the LLC Farm Enterprise "Partner", Mikhailovsky District of the Altai Region, one of the basic sites of the "Kulunda" project. The field experience was founded in 2013, implemented over the next four years in a similar way; the alternation of crops was carried out in accordance to the crop rotation. In total, there were four sets of experiments in eight variants in triple number of replications. There were four variants of row spacing implemented: $25.0 \mathrm{~cm}, 33.3 \mathrm{~cm}, 37.5 \mathrm{~cm}$, and $50.0 \mathrm{~cm}$. We also used two seeding rates for every crop: spring wheat - 75 and $120 \mathrm{~kg} / \mathrm{ha}$; rapeseed -2 and $4 \mathrm{~kg} / \mathrm{ha}$; peas 140 and $180 \mathrm{~kg} / \mathrm{ha}$. The sowing was made with an expimental grain seeder "Cornor-DMC" with chisel-shaped copying coulters, the "Amazone" company production. Combine harvesters "Lexion" (peas and rapeseed) and "Sampo" (wheat) carried out harvesting in August-September. As an object of research, the technological process of cultivation of agricultural crops in the crop rotation of spring wheat-pea-spring wheat-rape was considered. The influence of the row spacing and the seeding rate on the yield was evaluated. An increase in row spacing from $25 \mathrm{~cm}$ to $50 \mathrm{~cm}$ leads to an almost linear decrease in the yield of crops. The increasing of the seeding rate in the studied limits leads to the yield enhancement. The obtained data will allow substantiating the rational row spacing, design of the sowing complex and seeding rate. This is extremely important for introducing the "No-Till" technology in the arid steppe of the Altai Region.
\end{abstract}

Key words: Row spacing; Seeding rate; Crop yield; "No-Till” technology; Agriculture

\section{Introduction}

The technologies of saving agriculture are becoming more and more widespread under the conditions of the arid steppe of the Altai Region. One of them is "No-Till", which provides a significant reduction of anthropogenic impact on the soil, saving energy resources, preserving and restoring soil fertility in the long terms. This is an actual problem. Improving the efficiency of land use depends a lot on the correct choice of crops, their alternation in crop rotations and the substantiation of the seeding rate. When designing the parameters of sowing complexes, the row spacing is important. It is determining the parameters of the sowing complex during seeding, the distribution of seeds on the field, the further development of plants, the soil water regime and the yield. All these issues were studied in the framework of the International Russian-German Research Project "Kulunda" in 2011-2016 (Belyaev et al., 2014, 2016, 2017a, 2017b, 2017c).

\section{Materials and methods \\ Study site}

The long-term field experience has been carried out in the LLC Farm Enterprise "Partner", Mikhailovsky District of the Altai Region, one of the basic sites of the "Kulunda" project (Figure 1). The field experience was founded in 2013, implemented over the next four years in a similar way; the alternation of crops was carried out in accordance to the crop rotation. In total, there were four sets of experiments in eight variants in triple number of replications. 


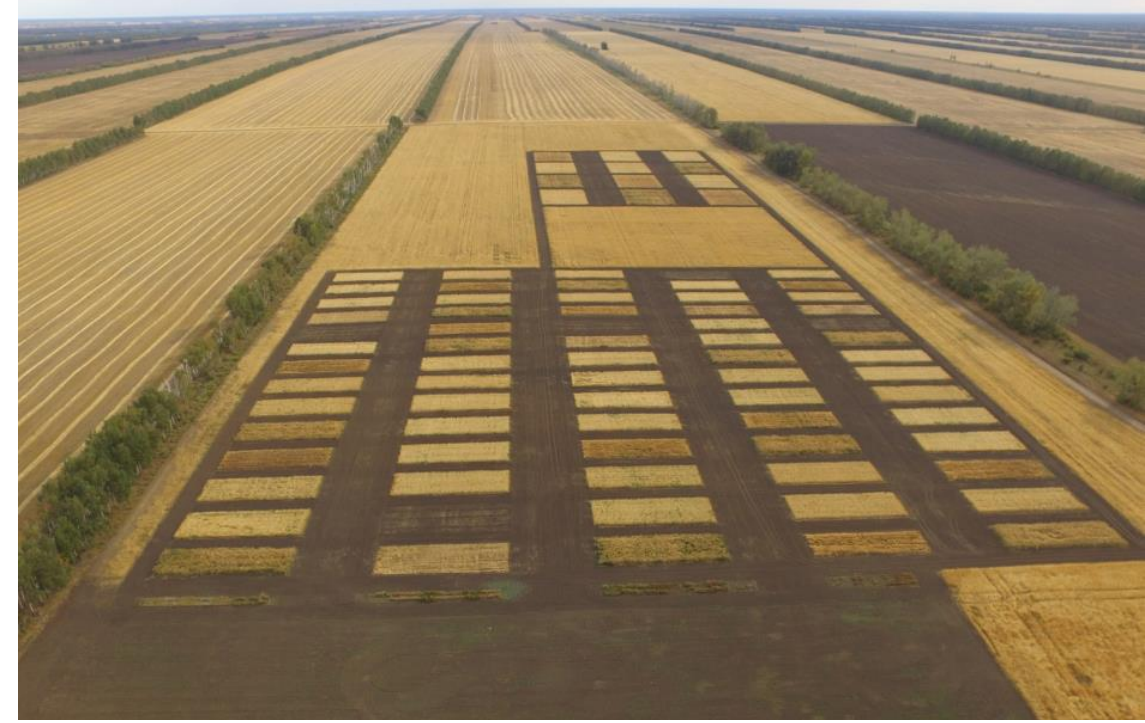

Figure 1. Experimental plots, LLC Farm Enterprise "Partner", Mikhailovsky District of the Altai Region (from: www.kulunda.eu).

\section{Crop and agrotechnical characteristics}

There were four variants of row spacing implemented: $25.0 \mathrm{~cm}, 33.3 \mathrm{~cm}, 37.5 \mathrm{~cm}$, and $50.0 \mathrm{~cm}$. We also used two seeding rates for every crop: spring wheat - 75 and $120 \mathrm{~kg} / \mathrm{ha}$; rapeseed 2 and $4 \mathrm{~kg} / \mathrm{ha}$; peas 140 and $180 \mathrm{~kg} / \mathrm{ha}$. The sowing was made with an experienced grain seeder "Cornor-DMC" with chisel-shaped copying coulters, the "Amazone" company production (Figure 2). Combine harvesters "Lexion" (peas and rapeseed) and "Sampo" (wheat) carried out harvesting in August-September.

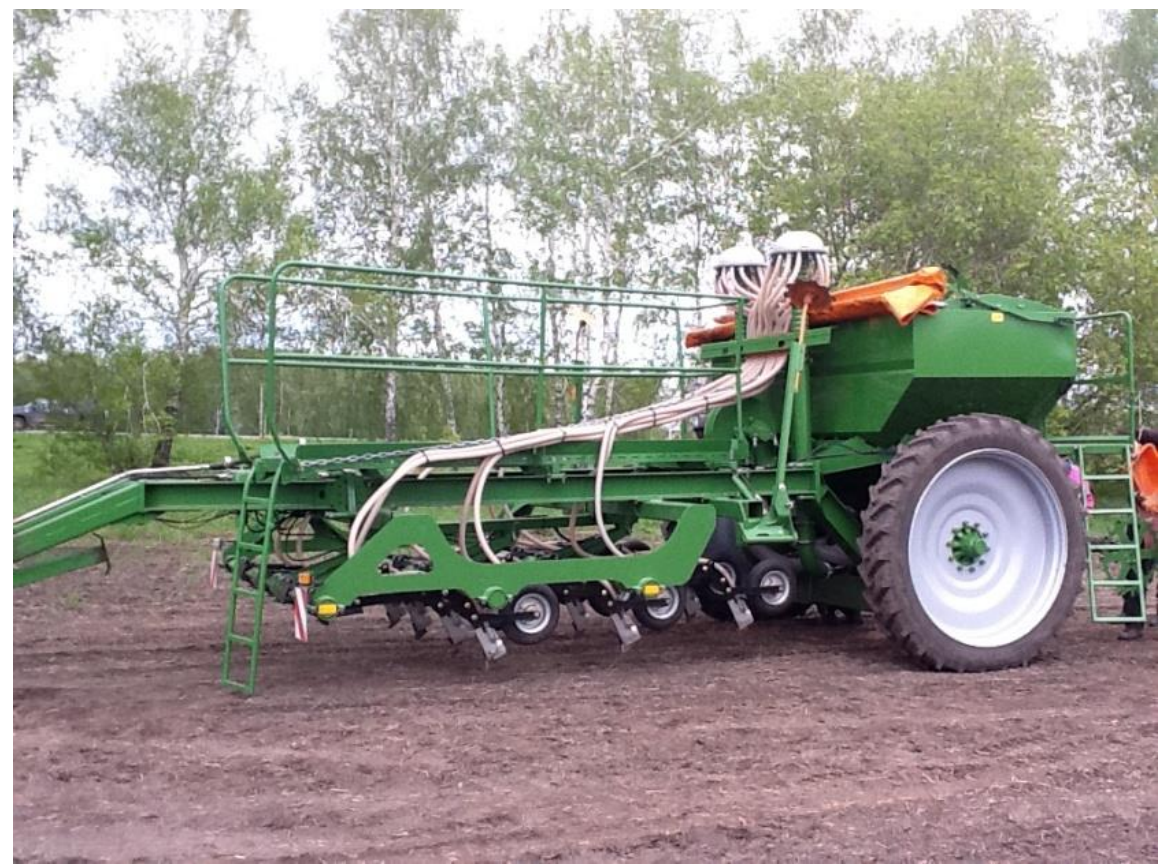

Figure 2. Experimental grain seeder "Condor-DMC", "Amazone", for sowing field experiments.

The variety of spring wheat "Altaiskaya-105": mass of 1000 grains $37.9 \mathrm{~g}$, laboratory germination rate $93.8 \%$. Sowing was performed at the end of the second - in the beginning of the third decade of May. The dose of fertilizer during sowing was $100 \mathrm{~kg} / \mathrm{ha}$ of ammonium nitrate. Before sowing the wheat the plots were treated by the preparation "Aristotel" at a dose of $2 \mathrm{~L} / \mathrm{ha}(100 \mathrm{~L}$ of water $+480 \mathrm{~g}$ active substance). During the growing season the plots was treated with mixture (100 L of water, $0.25 \mathrm{~L} / \mathrm{ha}$ "Toptun" +20 g/ha "Status Grand" + 0.7 L/ha "Avansis"). The variety of peas "Jamalskiy": mass of 1000 grains 170.0 g, laboratory germination rate $84.5 \%$. Sowing was performed at the second decade of May. The dose of fertilizer during sowing was $50 \mathrm{~kg} / \mathrm{ha}$ of ammonium nitrate in physical weight. The variety of rapeseed "Sidalgo": mass of 1000 grains $4.4 \mathrm{~g}$, laboratory germination rate $94.5 \%$. Sowing was performed at the second decade of May. The dose of fertilizer during sowing was $100 \mathrm{~kg} / \mathrm{ha}$ of ammonium nitrate in physical weight. During the growing season the pea and rapeseed plots was treated with the preparation "Forward" at a dose of $1 \mathrm{~L} / \mathrm{ha}$.

\section{Measured parameters}

As an object of research, the technological process of cultivation of agricultural crops in the crop rotation of spring wheat-pea-spring wheat-rape was considered. The influence of the row spacing and the seeding rate on the yield was evaluated.

\section{Statistical analysis}

The average data and the correlation between the yield of spring wheat, the row spacing and the seeding rate were designated. 


\section{Results and Discussion \\ Weather conditions}

The weather conditions of the growing season over the years of research are described in detail in other articles (Belyaev et al., $2014,2016,2017 a)$. The analysis shows that in the period of May - August the amount of precipitation ranged from 123.0 to 180.0 $\mathrm{mm}$ with average value of $148.2 \mathrm{~mm}$. This is lower than the multi-year mean by $20.4 \mathrm{~mm}(12.1 \%)$. Principally, less precipitation during the growing season was observed in June $(24.7 \mathrm{~mm}$ or almost in 2 times lower than the norm). The average monthly temperatures for 4 years of research were at the level of long-time average, except for May, where the decrease was $1.7^{\circ} \mathrm{C}$. The sum of the temperatures of the growing season was $38^{\circ} \mathrm{C}(1.7 \%)$ lower than the long-time average.

\section{Yield of crops}

Table 1 shows the average data of crop yield for the compared variants of the row spacing and the seeding rate in 2013-2016. As the analysis shows, the yield of cultivated crops largely depends on the studied factors. Thus, depending on the crops and fore crops, the average yield was within from 11.5 centners/ha (rapeseed) to 15.9 centners/ha (spring wheat for peas). An increase in the seeding rate for all crops sown led to an increase in yield by from 2.0 centners/ha (peas and rapeseed) to 4.7 centners/ha (spring wheat for peas). In addition, with an increase in the row spacing from $25.0 \mathrm{~cm}$ to $50.0 \mathrm{~cm}$, the crop yield decreased by 2.7 centners/ha (peas), 4.9 centners/ha (spring wheat after rape), and 7.2 centners/ha (spring wheat after peas). On the plots with spring wheat after peas the maximum yield was with the row spacing of $33.0 \mathrm{~cm}(13.1 \mathrm{centners} / \mathrm{ha})$, and the minimum - with the row spacing of $50.0 \mathrm{~cm}(10.2$ centners $/ \mathrm{ha})$.

Table 1. Average yield in the variants with different row spacing and seeding rates, 2013-2016.

\begin{tabular}{ccccccc}
\hline \multicolumn{3}{c}{ Sowing parameters } & \multicolumn{4}{c}{ Yield, centners/ha } \\
\hline No & Row spacing, cm & $\begin{array}{c}\text { Seeding } \\
\text { rate* }\end{array}$ & Peas & Wheat after peas & Rapeseed & $\begin{array}{c}\text { Wheat after } \\
\text { rapeseed }\end{array}$ \\
\hline 1 & 25.0 & 1 & 15.0 & 21.5 & 12.5 & 19.0 \\
2 & 25.0 & 2 & 12.2 & 16.5 & 11.4 & 14.3 \\
3 & 33.0 & 1 & 13.6 & 18.8 & 14.3 & 17.6 \\
4 & 33.0 & 2 & 12.8 & 15.5 & 11.9 & 14.4 \\
5 & 37.5 & 1 & 12.7 & 18.3 & 11.4 & 13.3 \\
6 & 37.5 & 2 & 11.2 & 13.3 & 11.9 & 14.4 \\
7 & 50.0 & 1 & 12.3 & 14.4 & 8.5 & 9.2 \\
8 & 50.0 & 2 & 9.4 & 9.2 & & \\
\hline
\end{tabular}

* - the numbers 1 and 2 are the lower and upper levels of the seeding rate.

\section{Linear equations}

Processing of field experience data allowed us to obtain the following linear equations of the connection of the physical yield of crops depending on the studied factors:

1. Peas: $Y_{f}=12.3-1.45 V_{1}+1.00 V_{2}, R=0.94$

2. Wheat after peas: $Y_{f}=15.6-3.64 V_{1}+2.31 V_{2}, R=0.99$

Wheat after peas: $Y_{f}=15.6-3.64 V_{1}+2.31 V_{2}$, $R=0$
Rapeseed: $Y_{f}=11.4-1.11 V_{1}+1.01 V_{2}, R=0.82$

4. Wheat after rapeseed: $Y_{f}=14.6-2.52 V_{1}+1.99 V_{2}, R=0.97$

Where: $Y_{f}$ - Physical yield, $V_{1}$ - Row spacing, $V_{2}$ - Seeding rate, $R$ - Correlation coefficient.

The analysis shows that in the studied range of the row spacing $(25.0-50.0 \mathrm{~cm})$ the greatest yield decrease with an increase in the row spacing was obtained on the plots with spring wheat sowings after peas (3.64 centners/ha for every $12.5 \mathrm{~cm}$ of spacing increase) and the minimum on plots with rapeseed (1.11 centners/ha). With an increase in the seeding rate, the highest yield growth was observed on the plots with spring wheat sown after peas and rapeseed $(2.31$ centners/ha and 1.99 centners/ha, respectively, by every $22.5 \mathrm{~kg} / \mathrm{ha}$ of seeding rate). The minimum was observed on the plots with peas $(0.01$ centners/ha for every $20 \mathrm{~kg} / \mathrm{ha}$ of seeding rate) and with rapeseed ( 0.01 centners/ha for every $1.0 \mathrm{~kg} / \mathrm{ha}$ of seeding rate).

\section{Conclusion}

The results of the field experiment indicate a high significance of the influence of all the studied factors on the crop yield. An increase in the inter-row spacing from $25 \mathrm{~cm}$ to $50 \mathrm{~cm}$ leads to an almost linear decrease in the yield of crops. The increasing of the seeding rate in the studied limits leads to the yield enhancement. The obtained data will allow substantiating the rational row spacing, and, consequently, the design of the sowing complex, as well as the seeding rate of crops, taking into account the impact on yield and economic efficiency indicators when introducing the "No-Till" technology in the arid steppe of the Altai Region.

\section{Acknowledgments}

The authors thank S.A. Kozhanov, A.A. Kozhanov and N.A. Kozhanov, Russia, for assistance in organizing and conducting field experience.

\section{References}

Belyaev, V.I., Meinel, T., Kozhanov, S.A., Tissen, R., Belyaev, V.V., Kozhanov, N.A. (2014). International project "Kulunda": the rationale for innovative machinery and technology systems for the cultivation of crops for the steppe zone of the Altai Region. Agrarian Science for Agriculture. Proceed. IX Int. Sc. Conf. Barnaul (in Russian).

Belyaev V.I., Meinel T., Grunwald L., Schmidt G., Bondarovich A.A., Shcherbinin V.V., Ponkina E.V., Matsyura A.V., Stefan E., Illiger P., Kozhanov N.A., Rudev N.V. (2016). The water regime of the soil and the yield of agricultural crops under various cultivation technologies in the Kulunda steppe of the Altai Region. News of Dnepropetrovsk University. Biology. Ecology, 24(2), 531-539. (in Russian). DOI: https://doi.org/10.15421/011672

Belyaev V.I., Bondarovich A.A., Ponkina E.V., Shcherbinin V.V., Schmidt G., Matsyura A.V., Kozhanov S.A., Rudev N.V. (2017a). The temperature regime of air and soil according to the meteorological and soil-hydrological monitoring network in the Kulunda plain during the vegetation periods of 2013-2016. Bulletin of the Altai State Agricultural University, 3(149), 30-36. (in Russian). 
Belyaev, V.I., Sokolova, L.V., Kuznecov, V.N., Matsyura, A.V. (2017b). Effect of sowingaggregates on sowing quality of spring soft wheat (the case of moderate dry-forest steppe, Altay region). Ukrainian Journal of Ecology, 7(3), 258-263. (in Russian). DOI: https://doi.org/10.15421/2017 77

Belyaev, V.I., Rudev, N.V., Maynel, T., Kozhanov S.A., Sokolova L. V., Matsyura, A.V. (2017c). Effect of sowing aggregates for direct sowing, sowing seeding rates and doses of mineral fertilizers on spring wheat yield in the dry steppe of Altai Krai. Ukrainian Journal of Ecology, 7(4), 145-150. (in Russian). DOI: https://doi.org/10.15421/2017 77

\section{Citation:}

Belyaev, V.I., Meinel, T., Rudev, N.V., Grunwald, L.-Ch., Sokolova, L.V., Kuznetsov, V.N., Matsyura, A.V. (2019). Influence of row spacing and seeding rate on crop yields cultivated by the "No-Till" technology in Kulunda steppe (Altai Region). Ukrainian Journal of Ecology, 9(3), 335-338.

This work is licensed under a Creative Commons Attribution 4.0. License 